\title{
Relationships and Structure: Male and Female Saudi Principal Perspectives of School Leadership, Challenges, and Responses
}

\author{
Linda R. Vogel \\ University of Northern Colorado
}

\author{
Ahlam Alhudithi \\ University of Northern Colorado
}

\author{
Abdulmohsen Alsliman \\ University of Northern Colorado
}

This qualitative study examined Saudi male and female principal perspectives regarding their work as school leaders, the challenges that they encounter, and how they respond to those challenges adding to the research on Saudi principals and particularly Saudi female principals. The findings indicated that female principals hold a communal view of school leadership, challenges, and responses to challenges in which relationships and meeting stakeholder needs are prioritized as compared to an agentic, self-oriented view of leadership tasks, procedures, and structural issues by male Saudi principals. Using grounded theory to analyze open-ended survey responses, theories were developed for both genders of Saudi principals and are discussed in relation to prior research as well as recommendations for pre-service Saudi principals and policymakers.

Keywords: principal, Saudi school system, school leaders, gendered leadership

\section{INTRODUCTION}

Saudi Arabia is a country with a historically patriarchal social structure rooted in Wahhabism, a conservative Islamic doctrine, that had greatly limited the education of women through the latter part of the twentieth century (Abalkhail, 2016; Alyami, 2016, Gorny, 2016; Metcalfe, 2011). Prior to 1960, informal schooling at home or in segregated religious schools provided girls with a basic understanding of the Quran and practical subjects to prepare them for their roles as wives and mothers (Alyami, 2016; Arar \& Oplatka, 2016). In the 1960s, girls were allowed to attend segregated elementary, middle, and secondary schools in response to the trend of Saudi men marrying foreign women "due to the lack of educated Saudi women" (Alyami, 2016, p. 868), ironically basing the education of women on the marital needs of Saudi men.

With the establishment of the first university for women in 1979, women were allowed to earn degrees in a limited range of fields that were viewed as appropriate to their role in society as caregivers. The majority of women who obtained higher education degrees went into the field of education, teaching primarily at the elementary level as this was considered appropriate for their social role as caretakers of children (Arar \& 
Oplatka, 2016). King Abdullah Bin Abdulaziz, however, has actively supported women assuming leadership roles in various economic sectors, particularly in education, by appointing a woman as the Vice Minister of Education in 2009 and giving women the right to vote in 2015 (Alyami, 2016).

The enrollment of more women than men in Saudi universities has resulted in a growing number of women in educational leadership positions even though women are still only allowed to teach at or lead schools for girls only (Arar \& Oplatka; Saudi Ministry of Education, 2016a). Given that bias against women leaders is still a challenge in nonsectarian nations such as the United States where women have struggled for equal rights for over a century, women in Saudi Arabia face even greater challenges in obtaining and serving in leadership roles because leadership attributes have been ascribed to men for centuries by patriarchal Islamic norms (Albakry, 2016; Aldawsari, 2016; Arar \& Oplatka, 2016; Carli \& Eagly, 2016, Eagly \& Karau, 2002; Schock et al., 2018; Yoder, 2001). Saudi women who serve as principals face the challenge of not only gendered leadership expectations but also the demands of managing and serving as the instructional leaders within a Saudi education system that was reformed in 2007 by King Abdullah in order to make the nation more economically competitive (Arar \& Oplatka, 2016; Meemar, 2014; Tayan, 2017).

New authorities were given to Saudi principals by the King Abdullah Public Education Development Project, also known as the Tatweer education reforms, with the goal of increasing Saudi student literacy and numeracy to meet both national and global labor market needs (Meemar, 2014; Tayan, 2017). The decreased centralization of the Saudi education system through the Tatweer reforms placed more responsibility on principals regarding both the management and instructional leadership of schools (Khalil \& Karin, 2017; Meemar et al., 2018). This qualitative study compared the professional responsibilities, leadership challenges, and responses to those challenges reported by female and male Saudi principals to explore possible gendered differences in school leadership given the country's historical patriarchal social context.

\section{SAUDI ARABIA'S EDUCATIONAL SYSTEM}

The Saudi government invested $\$ 2.4$ billion in 2007 to implement Tatweer in order to modernize both curriculum and instruction, increase student learning, and provide professional development for leaders, managers, and all school staff (Meermar et al., 2018). A gradual implementation of decentralization gave new responsibilities to school principals that included personnel, budget, and operational decision-making (see Appendix A for complete list). A study by Allheaniy (2012) found that principals' attitudes were positive regarding administrative and technical authorities but more financial authorities were desired. Challenges to carrying out the new responsibilities assigned to principals identified by Alhumaidhi (2013) included inflexible structures, overwhelming administrative tasks, and a lack of qualified support staff. Secondary school principals reported using their technical authorities more than administrative authorities and felt that the Tatweer changes had improved the operation of their schools in a study by Alotaibi (2013). Meermar et al. (2018) found that principals felt they had limited ability to implement the authorities they had been given due to limited "resources, training, and administrative support" and identified the need for more authority over staff issues, school budgets, decision-making, and school operations (p. 11-13).

Before the MOE was created, any teacher could apply to be a principal with the sole criteria being teaching experience (Khalil \& Karim, 2016). There was no requirement of administrative experience or training for principals, although many first served as assistant principals. Tatweer introduced the

requirements of a Bachelor's degree, at least four years of teaching experience with an "A" grade on their most recent two teaching evaluations, and at least two years of experience as an assistant principal (Saudi Ministry of Education, 2016b). Meeting the requirements did not mean that a person was prepared to be an effective principal however (Altuwaijri, 2016; Khalil \& Karim, 2016).

Principal preparation programs were offered by seven national universities in collaboration with the MOE although the 300 school leaders who were admitted to these programs had to already be school principals (Altuwaijri, 2016). With the tight control of curriculum in these preparation programs by the MOE, Altuwaijri criticized the government's efforts as inflexible in meeting the needs of principals, limited 
in the number of principals served, and not addressing pre-service development of school leaders. Mathis (2010) reported that $75 \%$ of the principals she studied had independently pursued coursework and readings to build their knowledge of educational leadership. Khalil and Karim (2016) found that leadership training i Saudi Arabia still consisted of a few training centers that were segregated by gender with curriculum that had little applicability to practice. Karim (2014) found that $85 \%$ of the 180 principals studied had attended four to eight days of training and only $35 \%$ had received a full week of training regarding school leadership. Recommendations to improve Saudi principal preparation have included more training sites and online training opportunities, particularly to serve women who would need to be accompanied by a male guardian if travelling any distance from their homes so that more aspiring principals could enter school leadership positions with adequate knowledge and skills (Khalil \& Karim, 2016).

\section{Leadership and Gender in Saudi Arabia}

Even though King Abdullah appointed a woman as the Vice Minister of Education in 2019, included women in the national Shura Council in 2013, and gave women the right to vote in 2015; the powerful governing boards that determine Saudi educational policy remain "predominantly in the hands of the exclusively male religious authority" (Arar \& Oplatka, 2016, p. 102). Gorney (2016) observed that Saudi Arabia was the "most profoundly gender-segregated nation on earth" (p. 11) with male and female gender roles firmly rooted in patriarchal Islamic beliefs (Abalkhail, 2016; Alyami, 2016). Women are "expected to forfeit their professional promotion for the benefit of men's advancement to avoid undermining the patriarchal structure of Arab society" (Shapira et al., 2010, p. 705). Metcalfe (2011) used the term "Islamic Gender Regime" to describe the ascribed gender roles in Arab nations such as Saudi Arabia as follows:

Cultural processes assume that a woman will marry early; that her contribution to the family will be as a homemaker; that the household will be headed by a man and that the man will provide financially and "protect" the family. Male protection is seen as the justification for the exercise of authority over women in all areas of decision making that relates to the public sphere. (p. 133)

Male protection is manifested by ensuring gender segregation in public spaces, the assumption of appropriate roles by women with family obligations remaining primary, and close supervision of women outside of the home. Guardianship laws were relaxed and women were allowed to drive by royal decree in 2017, however the impact of these changes on the freedom of women have yet to be explored.

Leadership is viewed in Arab societies as "an exclusive male realm of activity" where "women are seen as unfit and lacking the necessary skills and ability to become leaders" (Arar \& Oplatka, 2016, p. 92).

"Masculine leadership behaviors" are viewed as unacceptable (Abalkhail, 2016, p. 167) which makes women doubt their ability to lead (Albalkhair, 2016; Alsubaihi, 2016; Arar \& Oplatka, 2016; Metcalfe, 2011). Saudi women are faced with the challenges of "lack of mobility; the salience of gender stereotypes; gender discrimination in the workplace; limited opportunities for growth, development, [and] career advancement; excessive workload cause by a lack of family-work balance; and gender-based challenges related to dealing with pregnancy" according to Al-Asfour et al. (2017, p. 184). While many of the challenges Saudi women face in assuming leadership roles are systemic and will require time to change, the development of self-confidence in women as leaders requires support by other female leaders as well as male leaders and family members (Abalkhail \& Allan, 2015; Arar \& Oplatka, 2016).

Leadership styles of women have been studied more extensively in Western countries such as the United States where patriarchal structures exist but are not as overt as in Saudi Arabia (Carli \& Eagly, 2016, Eagly \& Karau, 2002; Schock et al., 2018; Yoder, 2001). Interestingly, transformational leadership, which has been increasingly identified as the most effective form of leadership by research conducted in the United States, is more often demonstrated by women and encompasses traits and behaviors associated with traditional female roles such as collaboration and relationship building (Carli \& Eagly, 2016, Eagly, 2007). Transactional leadership which is associated with the agentic traits of being directive, maintaining a clear hierarchy between the leader and those led, using rewards systems to address performance, and sometimes 
taking credit for work delegated to others as the right of leadership has been found to more often be demonstrated by men (Eagly, 2007; Eagly \& Karau, 2002; Fitzsimmons \& Callan, 2016).

While research on the leadership of female Saudi principals is limited, more general research findings suggest Arab female educational leaders often adopt a leadership style more typically associated with masculine authority traits early in their careers (Arar et al., 2013) and then shift to a more androgenous style after their authority has been established (Oplatka, 2006). Abdul-Ghaffar (2011), however, characterized the leadership style of Saudi female principals as autocratic as compared to the analytic style of their male counterparts. Such differentiations and labels vary by cultural and organizational contexts according to Alsubaihi (2016), however patriarchal role norms may lead both men and women to view male leadership traits more positively as in Aziz et al.'s 2017 study of Pakistani principals where both genders viewed male principals as being better decision- makers. More research is needed to explore what differences and similarities might exist in both perceptions and behaviors between women and men who lead schools in the patriarchal context of Saudi society. These understandings may inform the further support and development of all Saudi school leaders in navigating the challenge of increasing student learning.

\section{METHODOLOGY}

The purpose of this qualitative study was to explore what female and male principals in Saudi Arabia identified as essential elements of their role as school leaders that they carried out on a regular basis as well as the challenged that they encountered in carrying out their roles. The participants in this study were also asked how they respond to those challenges that they have encountered. The research questions guiding this study were as follows:

(A) What do male and female Saudi principals identify as essential elements of their positions that they engage in on a daily basis?

(B) What challenges do male and female Saudi principals encounter in being school leaders and how do they respond to those challenges?

Saudi Arabia was selected as the focus of this study because of the systemic educational Tatweer reforms that gave principals more decentralized responsibility and the social changes that have positively impacted the opportunities for women to serve as school leaders in this Islamic-based patriarchal society (Arar \& Oplatka, 2016; Meermar et al., 2018). Responses by gender were considered important to explore what, if any, differences existed in how women and men who were school leaders perceived essential elements of their school leadership roles, challenges that they identified, and how they responded to those challenges given the traditionally rigid norms for the roles of women and men in Islamic religion, the national religion of Saudi Arabia, and subsequently the Saudi government.

A constructionist epistemology was used to examine the phenomenon of how Saudi male and female principals describe what they do on a daily basis to carry out their role as school leaders, encountering and responding to challenges along the way. The constructionist perspective allowed the researchers to focus on the meaning that each individual created regarding school leadership based on their unique beliefs and experiences (Crotty, 2013). In order to let the voices and perspectives of the participants be clearly heard, a grounded theory approach was used to analyze the data and organize the findings (Strauss \& Corbin, 2014; Vogt et al., 2012). The researchers hoped to limit the possible bias of predominantly Western views of male and female leadership by embracing an organic development of themes found in the data rather than imposing a Western framework of either gendered leadership or school leadership. Given the relative dearth of research on female Saudi educational leaders, the researchers felt it was more appropriate to approach the initial analysis of the study data descriptively rather than critically to focus on the voice of the participants of either gender. (Further analysis of the data as well as future research delving more deeply into the gendered experiences of Saudi principals using a critical theory perspective is recommended by the authors.)

To answer the research questions guiding this study, an open-ended electronic survey was developed regarding what participants did on a regular basis as school leaders, what challenges they encountered, and how they responded to those challenges. A variety of questions were asked regarding how the participants 
enacted their role as school leaders in order to see if actions were repeated across responses. Demographic information was also asked regarding gender; school size, type (private or public), and configuration (elementary, middle, high/secondary, or other); geographic area served (rural, suburban, or urban); and student population. Past administrative experience and educational background questions were also included on the survey in order to provide a better understanding of prior experiences of the participants that might influence what they perceived as challenges and how they responded to those challenges, particularly given the indications of early studies that experience and training significantly impact Saudi principals' perceptions of efficacy in carrying out the responsibilities given to them through the Tatweer reforms (Meemar et al., 2019).

After Institutional Review Board approval was granted, voluntary participation was sought from a snowball sample of principals in Saudi Arabia in a highly urban province. The researchers fluent in Arabic, one male and one female, first approached two to three school principals of the same gender (due to the strict segregation of genders in Saudi Arabia) who might be willing to participate in the study and then asked for recommendations of other principals who might also be willing to participate. Voluntary participation was indicated by completion of the online survey.

Participants in this study included 22 female and 19 male Saudi principals. Participants led both public and private schools supervised by the Saudi Ministry of Education (MOE). Participants' schools were diverse ranging from a newly opened school with 67 students to a school that had begun 50 years ago and had over 3,500 students enrolled. Over half of the female principals in the study led elementary schools or school configurations that included elementary grades which was not surprising since Saudi schools are still segregated by gender. Half of the male principals led high schools. All of the male principals and $86 \%$ of the female principals had taught before moving into school leadership, and 59\% of the women and $63 \%$ of the men in the study had held the position of assistant principal prior to becoming a principal. Each participant had earned a Bachelor's degree, but only three female principals also had earned a Master's degree.

Using NVIVO 11 software, the participants' responses were first open coded as recommended by Saldaña (2013). Axial codes were then developed among and between the male and female respondents separately. Axial codes were then collapsed to identify themes among the responses of each gender group. A model or theory of what each gender group identified as elements of what they do on a regular basis as a school leader, the challenges that they faced, and how they responded to those challenges were developed. Finally, the themes and theories that had emerged from the female and male principals' data were compared to identify differences between the two sets of responses.

\section{Limitations}

This study was intended as an initial exploration of how male and female Saudi principals described the essential elements of their school leadership as well as what challenges they encountered and their responses to those challenges using a small non-stratified sample. The limitations of this study include the following:

(1) Transferability of the findings is extremely limited by the small sample size ( $n=22$ women and 19 men serving as principals in Saudi Arabia). Thus, the findings of this study are accurate only for this particular group of respondents at the point in time that data were collected.

(2) The sample of male and female Saudi principals included in this study was not stratified to be representative of various school types (elementary, middle, or high school or other grade-level configurations) or location (rural, suburban, and urban). The findings are, therefore, not representative of the overall population of Saudi principals.

(3) The inclusion of only female and male Saudi principals also limits the transferability of the findings to principals in other Arab nations as specific Saudi MOE education policies may have influenced the participants' responses in this study.

(4) The use of an electronic survey may have limited the depth of responses as compared to possible responses in an individual interview format of data collection that would allow for follow-up questions. 
The initial face-to-face contact of the female researcher fluent in Arabic to explain the study and invite female principals to participate may have influenced the female participants to provide more detailed answers to the electronic survey as compared to the male participants who were contacted by phone or email by the male researcher fluent in Arabic. Recommendations that could address these limitations and increase the transferability of findings are discussed later in this article.

\section{FINDINGS}

Five themes emerged regarding daily activities of the female participants that included the supervision of teachers, completion of paperwork, meeting with parents and representatives from the MOE, interactions with students, and the maintenance of school safety. Three themes emerged as challenges faced by the female principals such as demands of the position, the lack of decision-making power, and the workload of implementing MOE reforms. The female principals responded to those challenges by seeking more knowledge and skills through professional development and developing relational skills. The relationships of each theme identified in the area of daily activities, challenges, and responses to challenges are depicted in Figure 1.

FIGURE 1

\section{THEORY OF SAUDI FEMALE SCHOOL LEADER PERCEPTIONS OF SCHOOL LEADERSHIP CHALLENGES AND RESPONSES IN RELATION TO DAILY PROFESSIONAL ACTIVITIES DAILY ACTIVITIES CHALLENGES RESPONSE TO CHALLENGES}

DAILY ACTIVITIES

(In order of frequency within the data)
CHALLENGES

RESPONSE TO CHALLENGES

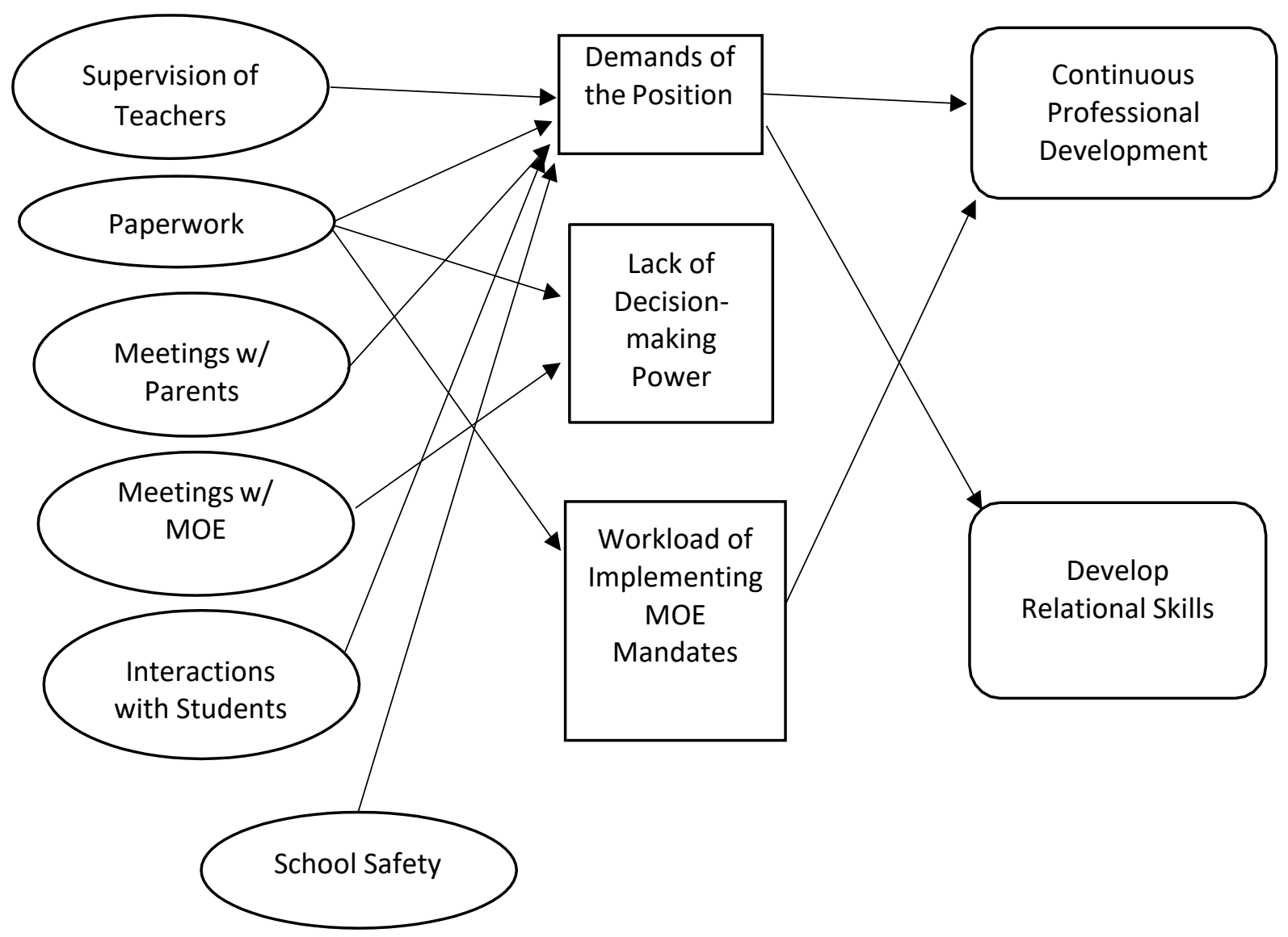


Five themes also emerged from the male principals' responses regarding daily school leadership activities including the supervision of instruction, addressing responsibilities and priorities, making decisions, following previously developed plans, and developing team spirit among school personnel. Challenges identified by the male principals included the duplication of work, the centralization of MOE power, and the lack of power, resources, professional development or training for staff, and qualified staff. The male principals' response themes to these challenges included developing a range of personal virtues, having a clear vision or goals, learning from others, preparing oneself, developing a good team, and developing better organizational skills such as the planning and delegation of work. The interrelation of the themes across the research question areas is depicted in Figure 2.

\section{FIGURE 2 \\ THEORY OF SAUDI MALE SCHOOL LEADER PERCEPTIONS OF SCHOOL LEADERSHIP CHALLENGES AND RESPONSES IN RELATION TO DAILY PROFESSIONAL}

DAILY ACTIVITIES

(In order of frequency within the data)
CHALLENGES

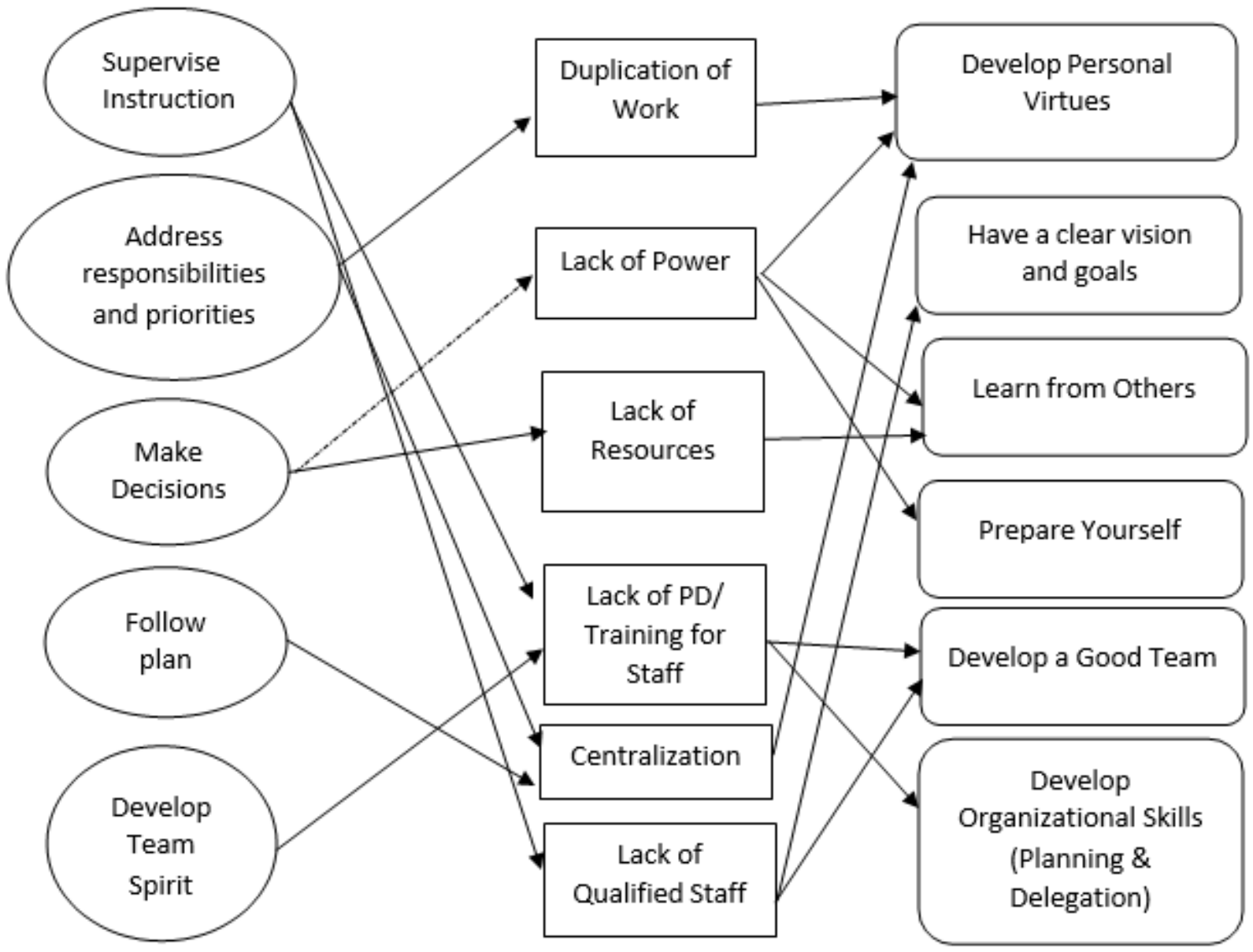

\section{Daily Leadership Activities}

Supervision of teachers' instruction emerged as the most dominant theme regarding essential elements of school leadership that all of the male and female Saudi principals in this study identified that they regularly engaged in on a daily basis. One woman in the study described how she makes time every day to attend different classes and then has collaborative discussions with the teachers afterwards. She explained, "I do not like the conversation with the teacher to be coming from one side by giving instructions; I like it 
to be from both sides where both of us create plans for improvement." Three-quarters of the female school leaders also discussed how the observation of classes and walk-throughs informed the professional development trainings that they scheduled for their teachers, sometimes tapping teacher leaders who have expertise in a particular area such as technology or delivering the training themselves. Meetings with others who also helped in the supervision of teachers (such as assistant principals, department heads, and academic assistants) were discussed as being daily activities that the women in this study used to stay informed about and guide the improvement of instruction in their schools.

The male principals also all discussed teacher supervision as a daily activity, however the descriptions were more general, such as one principal who said that he always is "working with teachers to support students." The male principals also discussed having follow-up meetings with teachers to discuss their performance and any issues observed in classrooms as well as reviewing data and feedback from various stakeholders. Providing feedback to teachers was how male participants described their post-observation meetings with teachers rather than the collaborative exchange of ideas for improvement described by the female principals. The men in this study also noted using feedback from parents and "stakeholders" when supervising and evaluating teachers whereas the women only mentioned parent and other stakeholder input in terms of making decisions regarding overall school improvement.

Four additional themes emerged regarding the daily leadership activities of the female principals. These included the completion of paperwork, meeting with parents and MOE representatives, interactions with students, and the maintenance of school safety (in order of most to least frequency of discussion across the data by participants). Paperwork was noted by every woman in the study and included working on MOE reports, responding to letters and emails, analyzing student data, and reading MOE letters which many of the women reported as arriving daily with updates and new decisions. Over half $(63 \%)$ of the female principals reported meeting with parents and MOE officials on almost a daily basis as well. While parent meetings were more student-specific, the MOE meetings included discussions of new procedures and directives and inspection of how the school was meeting other mandated policies.

Interactions with students focused mainly on dealing with academic or behavior issues, although attending daily prayers with students and extra-curricular activities were also discussed by the female school leaders. One woman explained, "When one of my students comes to me and tells me about her/his problem, and I help her/him to solve that problem. This makes me very happy." Slightly more than a third of the women also discussed student safety as an aspect of their daily school leadership activities. Specific activities that they engaged in to keep their students safe included making sure students were never left unsupervised by teachers and supervising students themselves as necessary and performing building inspections to make sure the facilities were clean and that there were no areas where students could incur an injury.

The other four themes that emerged from the male principals' responses included addressing responsibilities and priorities, making decisions, following already developed school plans, and developing camaraderie among school personnel. Responses regarding handling responsibilities or addressing priorities and decision-making were very concise and general. Examples of the former theme include "Check out the school's priorities, and direct it to follow- up tracking of daily tasks" and "The day is filled with responsibilities." These types of comments were made by $42 \%$ of the men in the study, and decisionmaking was noted by a little over a third of the men (36\%) with all of them simply saying that they spent time making decisions without any elaboration as to what those decisions pertained to. Following strategic plans for school improvement or teacher supervision and evaluation plans were noted by $32 \%$ of the male principals. One man stated that his daily activities were determined "according to the school's strategic plan" which was representative of the other responses in this theme. Although developing a team was only discussed by $26 \%$ of the male principals, comments were lengthy in describing sharing their vision to unite everyone into a team. One man explained that he tries every day "to work with everyone in the spirit of one team and inspire the spirit of trust and sharpen inspiration and overcome the difficulties and be guided in the commitment and discipline and creativity and achievement... of positive ideals." Another principal discussed how he worked with "teachers, administrators, and workers in the spirit of one team [to] overcome the difficulties and find alternatives that achieve the objective of education." 


\section{Challenges and Responses \\ Female Principals}

Three themes emerged from the female principal responses regarding challenges that they faced on a daily basis. These included the demands of the position, the lack of decision-making power, and the workload of implementing MOE reforms. All of the women in this study cited a variety of aspects of running their schools that were demanding including hiring and retaining teachers, managing the use of technology, parental expectations, and student behavior including motivation and moral development. A sentiment echoed by a third of the participants is summed up by one woman's explanation that "most of teachers that I have here are new teachers. They have no experience. They need intensive training and guidance. We provide training courses for them in topics such as planning strategies, learning styles, leadership styles, making decisions, and procedures because they tend to say 'we did know about this' [and] 'no one told us to do that,' so they need training." Technology concerns expressed by a little more than half of the women in the study focused mainly on keeping students' attention as shared by one woman who observed that, "Students have access to technology tools at home, and they learn things in a different way. They want to learn in classrooms using the same method and technologies that they play with outside of classes."

Difficulties meeting parental expectations were noted by $42 \%$ of the female participants with one woman summing it up by saying "You can't please everyone," particularly when it comes to providing a rigorous curriculum as well as high student achievement. Another woman shared an incident when "A parent told me that she will complain to the MOE about a teacher. She told me that she is a doctor and will contact the MOE. Unfortunately, the MOE always takes the students side even if they are wrong which has led many administrators to leave the position." The lack of decision-making power was identified as an ongoing challenge by $38 \%$ of the female principals with one woman explaining that, "I cannot make any decisions without contacting the MOE. All my decisions are to benefit students. Lacking the ability to make a decision make us feel untrusted." Another female principal said that she was frustrated that she could not even cancel the daily morning student assembly if the weather is bad without contacting the MOE. The stress of ever-changing initiatives and policies put forth by the MOE was identified by a third of the participants as a challenge the women in the study dealt with on a daily basis. One female principal provided the following explanation regarding this challenge:

The ministry always tries to develop the educational process and always creates new programs and procedures. This creates a problem because the MOE don't prepare stakeholders before requiring schools to implement these new programs. So the MOE creates new program, then they require schools to implement it, then they provide preparation courses after adopting wrong practices by school personnel. Also, we are required to implement many programs and activities during the school year which makes us distracted. I believe, if we only apply fewer programs, we can focus our attention on those programs and get a good impact out of them. Requiring schools to implement many programs in the same time makes the impact of these programs under satisfaction. This practice prevents us from getting the desired benefits.

This frustration with multiple new MOE initiatives, although well intended, was representative of the comments of the female study participants who discussed the challenge of implementing the MOE reforms.

The challenges discussed above were countered by the women in this study by increasing their knowledge and skills through professional development and trying to further develop their relational skills to handle issues with students, teachers, parents, and the MOE. Three-quarters of the female principals sought additional training in order to learn the best strategies to respond to the needs of students and to support teachers' instructional effectiveness. Organizational skills that allow a principal to lead rather than just manage was noted by the participants. One woman explained that "There is a difference between a manager and principal; the manager receives the instructions while the leader motivates people around to develop themselves." The development of decision-making skills that took into consideration the diversity 
of stakeholder perspectives and relied on collecting information before making a decision was viewed as the best way to make fair and constructive decisions in responding to the many demands of school leadership in ways that demonstrated care for others by the female Saudi principals.

\section{Male Principals}

Six themes regarding on-going challenges that the male principals faced were identified from the data. These included the duplication of work, the centralization of MOE power, and insufficient power, resources, teacher training, and qualified staff. Seventy percent of the men in this study cited the "overlap and duplication of work" as a significant challenge. Fifty-three percent of the male participants listed "MOE centralization" as a challenge to their work as school leaders. The "lack of powers granted to school leaders" or "lack of clarity of powers" were cited by $47 \%$ of male principals as a challenge that they faced which is a result of the centralization of power over educational decisions in the MOE, however the participants did not directly reference the MOE in these responses so they were grouped into a separate theme. The remaining three themes can be characterized by "the lack of" whether that was resources in general, training for teachers, or qualified teachers with $22 \%, 18 \%$, and $15 \%$ of male participants discussing each theme respectively. The responses were quite concise with comments such as "lack of equipment," "bad school buildings," "lack of professional development for teachers," and "difficult to hire effective teachers." The few additional explanatory comments made by the male principals focused on the skills needed by current and prospective teachers, particularly regarding active and constructivist teaching strategies and collaborative group learning.

The male principals' responses to these challenges were similar to the women's responses in that they focused on developing oneself. The men in this study focused on developing personal virtues, having a clear vision or goals, learning from others, preparing oneself, developing a good team, and developing better organizational skills. Patience and wisdom were two of the most frequently mentioned virtues that the male principals cited as useful in responding to leadership challenges. Sixty-percent of the men listed at least one virtue that they felt helped them to lead their schools. Having a clear vision or steadfast goal was identified by $48 \%$ of the men in this study as necessary to maintain a focus on the purpose of the school and education in general when dealing with challenging teacher situations. Learning from experienced principals ways in which to use what power and resources were available the most effectively was mentioned by $42 \%$ of the men, while $38 \%$ stressed that an aspiring principal must really prepare for the position in order to understand and work within the power and resource limitations. Selecting a good leadership team to assist in carrying out the supervision and training of teachers was emphasized by $36 \%$ of the male principals. Finally, developing strong organizational skills so that one can use their time effectively and also know when to delegate to others on one's leadership team was identified by $28 \%$ of the participants as important in providing necessary training to teachers to build their instructional skills.

\section{DISCUSSION}

This study examined what women and men who are Saudi principals identified as essential daily activities that they engaged in professionally as well as the challenges that they encountered and their responses to those challenges. The differences in responses between men and women were focused upon in the data analysis because Saudi Arabia is still governed by Islamic-based principles that have limited women's opportunities in the workplace although the current King has supported increased freedom and leadership opportunities for women. There are cultural forces that define the appropriate role of women in a narrow and stereotypical manner as wives and mothers and new social changes that have allowed women to take on roles outside of the home, particularly in education, that include becoming leaders such as school principals.

Although limited to leadership of schools of the same gender, men and women who are principals in Saudi Arabia must implement reforms handed down within a still centralized national educational system that require them to assume more of an instructional leader role within their schools as well as manage student conduct, building safety, and all of the human resource and public relations tasks that come with 
being a principal. Given the complexity of the position, especially with systemic reforms, the researchers wanted to learn whether there were differences between men and women who were Saudi principals in how they described what they do and how they dealt with challenges that they faced.

As the data was collected, a difference between the responses of the women and men in the study was immediately evident. Even though the data collection process was identical for both male and female principals in this study, the level of detail in responses varied dramatically between the two groups. The female participants responded to questions with detailed, descriptive answers whereas the male participants' responses were short and factual (with the exception of one male participant who did give more detailed and descriptive answers). While research on the differences in the use of language and communication between genders has found both similarities and differences (Eckert \& McConnell-Ginet, 2013; White, 2007), the responses of the participants in this study appear to reflect the differences that Joshi et al. (2020) found regarding the level of abstraction used by men and women in professional settings. They found that women tended to communicate in more concrete terms and used more descriptive details whereas men communicated in more abstract terms with less details. The role of context on communication is large and complex (Eckert \& McConnell-Ginet, 2013) however, so the differences in responses between the women and men in this study could also be influenced by perceptions of the significance of their responses with the women assigning greater value to the opportunity to discuss their positions as school leaders.

Differences between the gender of the participants also emerged in what they focused on as typical prioritized tasks that were elements of their roles as principals. The perspectives expressed by the women's responses focused predominantly on serving or working with particular groups of stakeholders while the men's responses focused more on procedural or structural duties. As one female principal explained, "I have the desire to guide the behaviors in the society, and the student is the basic unit of the society. I deeply believe that educational leadership is not a position by itself, but it is what the leader provides for his/her students." Another woman said that she wanted to lead "a school that attracts students and teachers, have many activities, and stakeholder who work as one team in order to succeed together." The women discussed meeting with teachers, parents, and students on a regular basis in order to improve student achievement.

Although the most frequently discussed daily activity by both the men and women in the study was supervision, the female principals described working with teachers in a variety of ways in the supervision process whereas the male principals consistently reported that they supervised instruction rather than teachers. Aside from the completion of paperwork, the female principals reported most of their day as being spent interacting with teachers, parents, Ministry representatives, and students. Even school safety was framed in terms of keeping the students safe. The male principals identified duties focused on their own follow-through rather than meeting the needs of stakeholders. The men's responses were more general and procedural such as "supervision of the educational process" or "supervisor, critic, and developer of the educational process."

In the area of challenges that participants encountered as school leaders, the lack of power was identified by both genders. The female principals overwhelming discussed the demands of the position in meeting all the needs of the various stakeholders more than the lack of decision-making power, however. The burden of paperwork to meet Ministry reform mandates was the only structural challenge identified by the female principals in this study. The male principals enumerated more challenges focused on the educational system structure particularly the redundancy of work required by different levels of Saudi educational governance. In both the daily activities as school leaders and the challenges that were encountered, the female principals framed their work in terms of people, relationships, and expectations or needs of others while the male principals couched their work in more self- focused terms and saw challenges as being structural issues.

Finally, the female principals sought more knowledge and skills on their own and developed skills to strengthen relationships among stakeholders to respond to the challenges they identified. The male participants reported developing more personal strengths or virtues to respond to their challenges, but the virtues were more self-focused with perhaps the exception of being a role model to others (although this, too, could be viewed as enhancing other's perceptions of one's self). Learning from others (such as other good school leaders) and preparing oneself (often with little or no further detail of what that preparation 
should entail) also seemed to focus on the male respondent rather than stakeholders, but this could be perhaps attributed to the structural nature of the challenges that the men identified. The other responses to challenges identified by the male principals also focused on procedural or structural changes such as having a clearly articulated vision and goals, developing a good team, or planning and delegating work better. As with the articulation of what the work of being a school leader entailed, the female principals in the study viewed challenges and their responses in relational terms as compared to the male emphasis on structural or procedural terms.

These differences in responses between men and women in this study could be attributed to the "ethic of care" often associated with women (Gilligan, 1982; Kropiewnicki \& Shapiro, 2001) that often manifests as placing a greater emphasis than men on relationships, developing more horizontal relationships, being more collaborative, and ultimately demonstrating a transformational leadership style that empowers and inspires followers (Hallinger et al., 2016; Shaked et al., 2018). Research has found that male leaders tend to demonstrate a more transactional leadership style that is directive, relies on formal authority with a clear organizational hierarchy, and focuses on procedure or structure over relationships (Hallinger et al., 2016; Shaked et al, 2018). Whereas the women in this study emphasized working with others in the various duties as principals and in responding to challenges they faced, the men frequently pointed to organizational structures that granted or limited their decision-making power and dictated their responsibilities.

Ultimately, the question becomes one of "Does gender in school leadership matter?" Whether there are differences in the way men and women lead is highly debated (Eagly \& Johanneson-Schmidt, 2002), and Fuller (2010) explained that gender is fluid and cannot be accurately assessed by viewing men and women as homogeneous groups. Grogan (2014) pointed out that gender and leadership "appears to be less interesting than it was previously - not surprisingly — since the prevailing attitude among many women and men is that gender is irrelevant" (p. 6). There are many studies, however, that have arrived at the same conclusion as Grogan that "gender seems to matter just as much today as it always has" $(2014$, p. 6). Earlier, Grogan and Shakeshaft (2011) had conducted a review of gender leadership studies and identified five leadership approaches that women demonstrated in various contexts, one of which was relational leadership. Torrance et al. (2017) found that female school leaders in Scotland, England, Jamaica, and New Zealand identified experiencing leadership differently than their male peers. Shaked et al. (2018) also determined that gender still impacts how women and men view leadership and how they lead.

To the earlier question regarding whether gender matters in school leadership, the findings from this study would indicate the answer to be "yes." The responses of the women principals in this study reflected relational leadership as described by Grogan and Shakeshaft (2011) as well communal leadership traits identified by Eagly and Johannesen-Schmidt (2002) and Yaseen (2010) that are associated with transformational leadership (Halinger et al., 2016). The women in this study expressed communal perspectives focused on relationships whereas the men focused on tasks, structural problems, and more self-focused behaviors. Even though a third of the female participants could be characterized as being in the early career stage, they did not express more "masculine" leadership views contrary to some earlier research conducted with Arab female leaders (Arar et al., 2013; Oplatka, 2006) perhaps indicating wider acceptance of communal leadership than a decade or more ago.

\section{RECOMMENDATIONS AND CONCLUSION}

Given that the findings in this study indicated that there are differences between how women and men perceive and carry out their roles as principals, there are several recommendations that can be made for both practitioners and policy makers in Saudi Arabia. These include the following:

(1) Since the Tatweer educational reforms were intended to increase student-centered instruction which requires principals to assume the role of instructional leaders (Alnahdi, 2014, Khalil \& Karin, 2017), Saudi education policy makers would be well served to examine the literature regarding effective instructional leadership and provide professional development for all principals to support the implementation of more constructivist, student-centered pedagogical practices. Additionally, Saudi policy makers should examine the pace and consistency of 
mandates as well as the redundancy of work at different levels of the education system so that principals are able to devote the necessary time to instructional leadership to improve student learning outcomes.

(2) The Tatweer reforms were also intended to provide more decentralized authority to principals (Khalil \& Karin, 2017), however principals in this study experienced the reforms as an increase in responsibility without the necessary power to respond to local educational needs of students. The provision by the MOE of more authentic power to principals so that they can shape local curriculum and instruction to respond to learners' needs is necessary.

(3) Both women and men who aspire to be principals in Saudi Arabia can learn from the findings of this study regarding the challenges that they are likely to encounter as a school leader and how to prepare themselves to deal with these challenges. This preparation can be enhanced by MOE professional development that addresses time management in the face of competing and complex role demands, staff and leadership team development, articulation of educational goals, and, perhaps most importantly, the development of relational skills in dealing with various stakeholders.

(4) Although much of the research on female leadership styles has been conducted in Western countries, the demonstration of transformational leadership characteristics by the women in this study indicated that women should embrace rather than doubt their leadership potential given the positive effects of transformational leadership (Eagly \& Johannesen-Schmidt, 2016). Professional development could be provided by the MOE to ensure that transformational leadership is a model that all Saudi principals understand and aspire to as school leaders.

Given the small number of participants in this study, several recommendations for future research can also be made. These are as follows:

(1) A replication of this study with a larger, stratified sample of women and men leading Saudi schools to increase the transferability of the findings. Stratification that addresses school types (grade-level configurations as well as public and private schools) and location (rural, suburban, and urban) would also make the findings more representative of the overall population of Saudi principals.

(2) This study could also be replicated with male and female principals in several Arab nations to identify specific national educational policies that may create school leadership challenges as well to better examine commonalities that might emerge related to cultural gender norms.

(3) The more explicit exploration of gendered experiences of Arab school leaders could yield greater insights into the impact of gender expectations on female school leaders.

(4) The use of individual interviews for data collection that would allow for follow-up questions which could produce more in-depth responses from male principals than what was gathered in this study and allow a greater understanding of male Saudi school leadership experiences. Interviews would allow for the voices of both male and female Saudi principals to be more fully heard and understood.

(5) Similar studies could also be conducted using a feminist critical theory epistemology to more fully examine the impact of gender and power on school leaders in Saudi Arabia.

(6) A study that specifically addressed how cultural and religious norms impact leadership views and actions of female and male principals in Saudi Arabia as well as other Arab nations could provide a more in-depth understanding of how gendered leadership is developed or constrained.

This study adds to the relatively small body of literature on Saudi principals, particularly female principals, by providing insight into the details of how Saudi male and female school leaders carry out their role as principals, the challenges that they face, and their responses to these challenges. It is hoped that the findings of this study will help both women and men aspiring to be principals in Saudi Arabia to understand and prepare for the position. These findings can also inform MOE policy makers regarding ways that they can better prepare and support principals so that the goal of better preparing Saudi students can be realized. While the Tatweer educational reforms and the increased opportunities for women to serve as leaders in 
Saudi Arabia are both tremendously positive steps, more can be done to support the effectiveness of the educational system and school leadership to ensure student achievement.

\section{REFERENCES}

Abalkhail, J.M. (2017). Women and leadership: Challenges and opportunities in Saudi higher education. Career Development International, 22(2), 165-183. http://dx.doi.org.unco.idm.oclc.org/10.1108/CDI-03-2016-0029

Abdul-Ghaffar, N.A. (2011). Management types and their relationships to the thinking styles of female principals in the secondary schools in Jeddah. Journal of Literature and Humanities, 24(1), 105152.

Albakry, A.H. (2016). Voices of women leaders in corporate institutions in Saudi Arabia. [Doctoral dissertation, University of San Francisco]. ProQuest Dissertations \& Theses Global Database. Retrieved from http://0search.proquest.com.source.unco.edu/docview/ 1798851077 ?accountid $=12832$

Allheaniy, B. (2012). Attitudes of principals in Makkah about the new authorities given to them. [Doctoral dissertation, Umm Alqura University]. ProQuest Dissertations and Theses.

Alnahdi, G.H. (2014). Educational change in Saudi Arabia. Journal of International Education Research, $10(1), 1-6$.

Alrashidi, O., \& Phan, H. (2015). Education context and English teaching and learning in the Kingdom of Saudi Arabia: An overview. English Language Teaching, 8(5), 33-44. Retrieved from https://eric.ed.gov/?id=EJ1075240\#: :text=This\%20paper\%20discusses\%20the\%20education $\% 2$ 0context $\% 20$ and $\% 20$ English,modern $\% 20$ education $\% 2 \mathrm{C} \% 20$ and $\% 20 \mathrm{a} \% 20$ description $\% 20 \mathrm{of} \% 20 \mathrm{t}$ he $\% 20$

Alsubaihi, S. (2016). Challenges for women academic leaders to obtain senior leadership positions in higher education in Saudi Arabia. [Doctoral dissertation, Pepperdine University]. ProQuest Dissertations and Theses. Retrieved from https://www-proquestcom.unco.idm.oclc.org/docview/1830466746?pq-origsite=summon

Altuwaijri, A. (2016). A comparison between Saudi and American school principal preparation programs. [Doctoral dissertation, Southern Illinois University]. Retrieved from https://wwwproquest-com.unco.idm.oclc.org/docview/1803939420?pq-origsite=summon

Alyami, R.H. (2016). Saudi women's education and work opportunities: Equity matters. International Journal of Technology and Inclusive Education, 5(2), 868-972. http://doi.org/10.20533/ijtie.2047.0533.2016.0111

Arar, K., \& Oplatka, I. (2016). Current research on Arab female educational leaders' career and leadership: A review of the extant literature and future directions for research. In B.G. Barnett, A.R. Shoho, \& A.J. Bowers (Eds.), Challenges and opportunities of educational leadership research and practice: The state of the field and its multiple futures (pp. 87-115). Information Age Publishing. Retrieved from https://www.arabtradeunion.org/upload/current\%20research\%20on\%20arab\%20female_0.pdf

Arar, K., Shapira, T., Azaiza, F., \& Hertz-Lazarowitz, R. (2013). Arab women into leadership and management. Palgrave McMillan.

Carli, L.L., \& Eagly, A.H. (2016). Women face a labyrinth: An examination of metaphors for women leaders. Gender in Management: An International Journal, 31(8), 514-527. http://doi.org/10.1108/GM-02-2015-0007

Crotty, M. (2013). The foundations of social research: Meaning and perspective in the research process. SAGE.

Eagly, A.H., \& Johannesen-Schmidt, M.C. (2002). The leadership styles of women and men. Journal of Social Issues, 57(4), 781-797. https://doi-org.unco.idm.oclc.org/10.1111/0022-4537.00241 
Fuller, K. (2010). Talking about gendered headship: How do women and men working in schools conceive and articulate notions of gender? Journal of Educational Administration and History, 42(4), 363-382. https://doi-org.unco.idm.oclc.org/10.1080/00220620.2010.514041

Gilligan, C. (1982). In a different voice: Psychological theory and women's development. Harvard University Press.

Gorney, C. (2016). The changing face of Saudi women. National Geographic, 229(2), 110-133.

Retrieved from https://unco.idm.oclc.org/login?url=https://www-proquest com.unco.idm.oclc.org/magazines/changing-face-saudi-women/docview/1781823764/se2? accountid $=12832$

Grogan, M. (2014). Re(Considering) Gender Scholarship in Educational Leadership. In C.K. Mansfield \& W.S. Newcomb (Eds.), Women Interrupting, Disrupting, and Revolutionizing Educational Policy and Practice (pp. 3-20). Information Age.

Grogan, M., \& Shakeshaft, C. (2011). Women and educational leadership. Jossey Bass.

Hallinger, P., Li, D., \& Wang, W.C. (2016). Gender Differences in Instructional Leadership: A MetaAnalytic Review of Studies Using the Principal Instructional Management Rating Scale.

Educational Administration Quarterly, 52(4), 567-601. https://doi.org/10.1177/0013161X16638430

Karim, M. (2014). An examination of principals' knowledge, training, leadership skills, authority, and the organizational support to implement the "New Vision" at "Developed Schools" in Saudi Arabia. [Doctoral dissertation, Howard University].

Khalil, D., \& Karim, M. (2016). Saudi Arabia: School leadership in Saudi Arabia. In H. Arlestig, C. Day, \& O. Johansson (Eds.), A Decade of Research on School Principals: Cases from 24 Countries (pp. 503-519). Springer International Publishing.

Kropiewnicki, M.I., \& Shapiro, J.P. (2001, April 10-14). Female leadership and the ethic of care: Three case studies. [Paper presentation]. American Educational Research Association, Seattle, WA, United States.

Meemar, S.S. (2014). Tatweer school principals' perceptions of new authorities granted in the initial steps of decentralization. [Doctoral dissertation, Western Michigan University]. Retrieved from https://scholarworks.wmich.edu/dissertations/384

Meermar, S.S., Poppink, S., \& Palmer, L.B. (2018). Educational decentralization efforts in a centralized country: Saudi Tatweer principals' perceptions of their new authorities. International Journal of Education Policy \& Leadership, 13(2), 1-16. https://doi.org/10.22230/ijep1.2018v13n1a730

Oplatka, I. (2006). Women in educational administration within developing countries. Journal of Educational Administration, 44(6), 604-624. https://doi.org/10.1108/09578230610704819

Saldaña, J. (2013). The coding manual for qualitative researchers. SAGE Publications.

Schock, A., Gruber, F.M., Scherndl, T., \& Ortner, T.M. (2018). Tempering agency with communion increases women's leadership emergence in all-women groups: Evidence for role congruity theory in a field setting. The Leadership Quarterly, 30(2), 189-198. http://doi.org/10.1016/j.leaqua.2018.08.003

Shaked, H., Glanz, J., \& Gross, Z. (2018) Gender differences in instructional leadership: How male and female principals perform their instructional leadership role. School Leadership \& Management, 38(4), 417-434, https://doi.org/10.1080/13632434.2018.1427569

Strauss, J., \& Corbin, A. (2014). Basics of qualitative research: Techniques and procedures for developing grounded theory (4th ed.). SAGE Publications.

Tayan, B.M. (2017). The Saudi Tatweer education reforms: Implications of neoliberal thought to Saudi education policy. International Education Studies, 10(5), 61-71. https://doi.org/10.5539/ies.v10n5p61

Torrance, D., Fuller, K., McNae, R., Roofe, C., \& Arshad, R. (2017). A social justice perspective on women in educational leadership. In P. Miller (Ed.), Cultures of educational leadership: Global and intercultural perspectives (pp. 25-52). Palgrave Macmillan Lt. 
Vogt, W.P., Gardner, D.C., \& Haeffele, L.M. (2012). When to use what research design. The Guilford Press.

Yaseen, Z. (2010). Leadership styles of men and women in the Arab world. Education, Business and Society: Contemporary Middle Eastern Issues, 3(1), 63-70. https://doi.org/10.1108/17537981011022823

Yoder, J.D. (2001). Making leadership work more effectively for women. Journal of Social Issues, 57(4), 815-828. https://doi.org/10.1111/0022-4537.00243

\section{APPENDIX}

Administrative and technical authorities granted to Saudi principals under Tatweer were as follows (Meemar et al., 2018):

\section{Administrative Authorities}

1. Choose an assistant principal from the list of names provided by the Department of Education.

2. Deduct pay from the employees' salaries when they are absent or late, and then inform the Department of Education to implement the decision.

3. Specify teachers who are to be transferred from one school to another school. These teachers should be those whose performance has decreased 85 percent in function over the last two years.

4. Transfer any employees $\mathrm{n}$ administrative jobs to other school if their performance has decreased from "excellent" in the last two years.

5. Evaluate bus drivers.

6. Apply models that support the proficiency of teaching and solve school problems.

7. Arrange studies to solve school issues.

8. Nominate not more than five employees for professional development in the school year.

9. Sign contracts with specialized parties accredited by governmental sectors related to operating the school cafeteria.

10. Adopt the naming of teachers who deserve a financial reward for teaching classes in which they substitute for an absent teacher in addition to working their won 24 credit hours.

11. Sign contracts with laborers for cleaning the school in the case contracts were impossible with the cleaning officers, or in the case the labor was contracted but not performed.

12. Contract with competent institutions to perform urgent maintenance for the school according to the specialized budget.

\section{Technical Authorities}

1. Make temporary modifications to the duration of classes and recess to realize educational needs.

2. Increase the duration of study for groups of students to approximately one hour at maximum per day.

3. Close the school in emergency cases for one day at maximum and officially inform the Department of Education.

4. Communicate directly with the governmental organizations in emergency cases.

5. Accept students who are out of the school district.

6. Determine when a student's behavior represents a danger against any school employee, and transfer the student to another school.

7. Add programs that address some of the school problems.

8. Execute specified school activities outside the school, for durations of no more than three days.

9. Contact the private sector to sponsor school programs that match school goals. 